\title{
A NEW NAME IN PTEROCEPHALUS (CAPRIFOLIACEAE) FROM KURDISTAN-IRAQ
}

\author{
Saleem E. Shahbaz ${ }^{\mathrm{a}, *}$ and Vameen Abozaid ${ }^{\mathrm{b}}$ \\ ${ }^{a}$ Dept. of Agricultural Engineering, Faculty Science,University of Duhok, Kurdistan Region, Iraq (saleem.shahbaz@uod.ac) \\ ${ }^{b}$ Dept. of Biology, Faculty of Science, University of Zakho, Zakho, Kurdistan Region, Iraq
}

\begin{abstract}
:
Pterocephalus tetraflorus S. E. Shahbaz, nom, nova, is proposed as a new name for Pterocephalus strictus Boiss. et Hohen, described by Boissier in1843, followed by Shahina and John in 2013. The description of $P$. tetraflorus is amended with characters of mature flowers and achenes, illustrated and its diagnostic characters, geographical distribution and habitats are presented. The species $P$. tetraflorus is closely related to $P$. strictus, but can be easily separated by forming only four-flowered capitula against numerous flowered-capitula for P. strictus and other Pterocephalus species.
\end{abstract}

KEYWORDS: Pterocephalus strictus, Involucre, Involucel, Plumose calyx, New name.

\section{INTRODUCTION}

The Caprifoliaceae of the order Dipsacacles is a family consisting of about 860 species (The Plant List, 2013.Version $1.1)$, in 42 genera. The family is of worldwide distribution, with the Centers of diversity in eastern North America and eastern Asia (Nicolson, 1991), but are absent from tropical and southern Africa. The broad sense of the family (Caprifoliaceae s.l.) is separated into 6 subfamilies: Dipsacoideae, Diervilloideae, Caprifolioideae s.l., Linnaeoideae, Morinoideae, and Valerianoideae. The subfamily Dipsacoideae is classified to contain genera: Pterocephalus, Cephalaria, Dipsacus, Knautia, Scabiosa, Succisa, Succisella, and Triplostegia (Sevens, 2001).

The most important genera of Iraq are Pterocephalus Vaill. ex Adans., Cephalaria Schrad. ex Roem. \& Schult., Dipsacus L., Scabiosa L., and Lonicera L.. The latter genus is represented by the very widely distributed small tree or shrub Lonicera arborea Boiss. in the mountains of Kurdistan.

Pterocephalus Vaill et Adanson is a genus of about 25 herbs and shrubs species from the Mediterranean to Central Asia, the Himalayas, and tropical Africa (Kriechbaum and Kletter, 2001). The genus has long been regarded as belonging to the Dipsacaceae, but according to APG III (2009), the genus is included within the larger family Caprifoliaceae (Reveal and Chase, 2011).

The calyx is the most easily observable diagnostic character of Pterocephalus; it is formed by numerous plumose bristles, but the presence of this character in some other genera such as in Pseudoscabiosa gives the impression of heterogeneity and made Verlaque (1986a, 1986b) suggest four separate phylogenetic lines within the Pterocephalus genus.

Four Pterocephalus spp. (P. pyrethriform Boiss. et Hoh. P. plumusus (L) Coult. $P$. kurdicus Vatk. and $P$. canus Coult. ex DC. ) are deposited in BAG (National Herbarium of Iraq). The same above mentioned 4 species were registered from Hawraman mountain track/ Sulaimani/Iraq (Ahmad, 2013). In Flora of Turkey and the East Aegean Island, Davis (1972) referred to the presence of the following taxa of the Dipsacaceae in mountains of Kurdistan-Iraq, sharing flora of
Turkey: P. pyrethrifolius, P. plumusus, P. kurdicus, P. strictus Boiss. et Hoh., P. brevis Coult., P. szovitsii Boiss. Only $P$. kurdicus, $P$. brevis, and $P$. canus species are found to share both floras of Turkey and Iran as Irano-Turanian elements. In the recent volume of Flora of Iraq, Shahina and John (2013) described 9 Pterocephalus taxa including P. strictus, growing mostly on rocky mountainsides, on grey soil with sandstone and limestone rocks, among Quercus scrubs, on dry silt and stony hillsides, at the altitudinal range of $180-1800 \mathrm{~m}$.

\section{MATERIALS AND METHODS}

During the past three years, the university of Duhok/Herbarium conducted an extensive floristic survey in Bykhair Mountain track, which is part of the Zagros Mountain range, overlooking Duhok and Zakho cities and occupying an area of about 1000 $\mathrm{km}^{2}$ between $36^{\circ} 51^{\prime} 58.634^{\prime \prime}$ to $37^{\circ} 06^{\prime} 44.256^{\prime \prime} \mathrm{N}$ and $042^{\circ}$ $40^{\prime} 23.886^{\prime}$ " to $043^{\circ} 05^{\prime} 49.846^{\prime}$ " E. the Bykhair mountain botanical survey yielded some novelties to the flora of Iraq including the current species .

The species with the new name was compared with all Pterocephalus specimens in Iraqi herbaria. Floras of Iraq (Shahina and John, 2013) and of the neighboring countries (flora of Turkey, Davis, 1972; flora of Iran, Rechinger, and 1963-2005) were consulted. The plant was found in locations shown in Figure 1. Morphological measurements for the description of the taxon were obtained from the living material collected from the field.

\subsection{Species description}

Plants shrubby, viscid perennials, $12-24 \mathrm{~cm}$ tall, mostly semiglobal in outline, $20-60 \mathrm{~cm}$ long, and $15-55 \mathrm{~cm}$ broad, densely furnished throughout by short glandular and long eglandular hairs. Stem woody, much-branched from the base, ascendingprostrate, provided by whitish scales. Leaves are glandularpubescent, leathery, and viscid on both surfaces, exstipulate, crowded at the upper part of the twig, highly variable in shape; 
petioles leafy, slender with a slightly flattened base. Lower leaves pinnatisect, few are simple, with slightly longer petioles, mostly soon caducous; lobes $2-5$, some with larger terminal lobes; blade 15.46-27.73(-38) $\mathrm{mm}$ long, $6.15-12.48 \mathrm{~mm}$ wide; petioles $3.1-18.83 \mathrm{~mm}$ long, $0.4-1.5 \mathrm{~mm}$ thick. Upper leaf blade obovate, elliptic, ovate-lanceolate, 11.61-23.74 mm long, 4.96$11,75 \mathrm{~mm}$ width, sometimes slightly asymmetric; margins coarsely, irregularly serrate; apex acute; base attenuate to narrowly attenuate; midribs distinctly raised from below; petioles 4.12-17.36 long, 0.45-174mm thick. Inflorescences scapiflorous, not radiate; ultimate units cymose; peduncles short, 2.31-7.74mm long hairy. Involucral bracts 4 , in one row, lanceolate-acuminate, hairy outside, glabrous inside, with 5-7 prominent veins, $4.5-8.89 \mathrm{~mm}$ long, $2.20-4.51 \mathrm{~mm}$ width, as about one third as flower length. Involucel cylindrical, 2.06$2.97 \mathrm{~mm}$ long, $1.39-1.57 \mathrm{~mm}$ width, densely hairy with tufts of hairs at base: ribs prominent, 6-8; corona short, white membranous at the Involucel apex, 0.2-0.3 $\mathrm{mm}$ width. Flowers are only 4 in capitula. Calyx plumose violet sitae, persistent on the ovary, shortly stipitate; setae $15-22,7.55-11.63 \mathrm{~mm}$ long. Corolla gamopetalous, 5 united petals; pink or whitish, funnelform, 14.32-16.37mm long: limb lobes subequal, obovateoblong, sparsely hairy outside, glabrous inside, $1.89-4.63 \mathrm{~mm}$ long $1.35-3.94 \mathrm{~mm}$ width; tube $5.45-8.87 \mathrm{~mm}$ long, 0.54 $2.49 \mathrm{~mm}$ diameter. Stamens 4 , inserted in the upper part of the corolla tube, variable in length but not didynamous, exserted; filament $5.94-11.72 \mathrm{~mm}$ long, $0.2-0.48 \mathrm{~mm}$ diameter; anthers $1.65-1.78 \times 0.6-1.1 \mathrm{~mm}$, dorsifixed dehiscing via longitudinal slits, introrse; style 1, slender, 10.74-15.26mm length, 0.61$0.34 \mathrm{~mm}$ diameter, exserted at maturity to the same level of stamens or slightly less. Stigma is $1,0.68-0.82 \mathrm{~mm}$ diameter, capitate; ovary inferior enveloped by involucels. Achene smooth-faintly ribbed, $3.10-6.13 \mathrm{~mm}$ long, $1.52-2.43 \mathrm{~mm}$ width. Seeds are with a smooth large, straight embryo (Figures 2, 3, 4, and 5).

Phenology: Flowering May-July, Fruiting Aug. - Sept.

Type: Iraq, Kurdistan, Duhok province, on a steep rocky small mountain valley, north Duhok city, below peak of Kiylia Firaeni of the Bykhair mountain track, south-west direction, altitude $712 \mathrm{~m}$, latitude $36^{\circ} 52^{\prime} 43.486 ” \mathrm{~N}$, longitude $042^{\circ} 59^{\prime}$ 11.083” E, 11 June/2017, Saleem Esmael Shahbaz (University of Duhok), 2017-3634. Holotype: DPUH (Duhok Province University Herbarium), Isotype: KBFH (Kurdistan Botanical Foundation Herbarium).

\subsection{Diagnosis and related taxa:}

Pterocephalus tetraflorus was easily recognized from all other species of Pterocephalus by having non-radiant capitula of only four flowers per each. It was closely related to P. strictus, but clearly differed from it in characters shown in the table 1. Table 1. Morphological differences between P. tetraflorus and P. strictus (Davis, 1972).

\begin{tabular}{|c|c|c|}
\hline Characters & P. tetraflorus & $\begin{array}{c}\text { P. strictus Boiss. } \\
\text { and Hohen. }\end{array}$ \\
\hline Leaves & $\begin{array}{c}\text { Lower leaves } \\
\text { pinnatisect and simple } \\
\text { Upper leaves obovate, } \\
\text { elliptic, ovate- } \\
\text { lanceolate, }\end{array}$ & Oblong-lanceolate \\
\hline Flowers & Four/capitula & $\begin{array}{c}\text { Numerous, usually } \\
\text { more than four, up } \\
\text { to 12/capitula }\end{array}$ \\
\hline Calyx & $15-22$ plumose setae & $\begin{array}{c}\text { About 12 plumose } \\
\text { setae }\end{array}$ \\
\hline
\end{tabular}

\section{Habitat and Distribution}

This species of the plant occurred in the dry very steep mountain gorge and mountain valleys, in calcareous cliffs, on rock faces, in crevices of cliffs where direct sun exposure reduces by about 2-3 hours in a day; at the altitudinal range of $578-848 \mathrm{~m}$. The plant avoids very cold sites, high altitude, deep fertile and damp places, it is usually observed growing with plants like Stellaria media (L.) Vill., Andrachne aspera Spreng., Sempervivum tectorum L, Umbilicus intermedius Boiss. Asperula asterocephala Bornm., Verbascum speciosum Schrad., and Parietaria judiaca L.

The plant is only found in lower mountain zone of Duhok province, quite local, but abundant in its growing locations. The characteristic habitat of steep slopes and crevices of cliffs prevents possible fires, grazing, and gathering of plants by local people, therefore this species is facing no considerable threats and its status can be treated as of least concern (LC) (IUCN Red List, 2012).

\section{CONCLUSION}

All specimens of Pterocephalus investigated from Duhok province and probably from Iraq are $P$. tetraflorus. Specimens investigated from eastern Turkey are $P$. strictus.

\section{REFERENCES}

Verlaque, R. 1986a. 1 tude biosyst $\sim$ matique et phylog $\sim$ n tique des Dipsacaceae. IV. Tribu des Scabioseae (phylum No 1, 2, 3). - Rev. Cytol. Biol. V6g\&. - Bot. 9: 5-72..

Verlaque, R. 1986b. 1 tude biosyst matique et phylog6n\&ique des Dipsacaceae. V. Tribu des Scabioseae (phylum No 4) et conclusion. - Rev. Cytol. Biol. V g6t. - Bot. 9: 97-176.

Ahmad, S. A. 2013. Flora of Hawraman Mountain. A dissertation submitted to the council of the faculty of agricultural sciences at the University of Sulaimani in partial fulfillment of the requirements for the degree of doctor of the philosophy of sciences in Agriculture-Plant Taxonomy.

Davis, P. H. ed. 1972. Flora of Turkey and the East Aegean Islands, Volume four, Dipsacaceae pages 582-625, Edinburgh: University Press.

IUCN Red List 2012. Guidelines for Using the IUCN Red List Categories and Criteria (PDF), Version 13, IUCN, March 2017, retrieved 2018-01-04.

Kriechbaum, M and; Kletter, C. 2001. Tibetan medicinal plants. Stuttgart: Medpharm. p. 270. ISBN 0-8493-0031-2.

Nicolson, Dan,1991. A history of botanical nomenclature. Annals of the Missouri Botanical Garden. 78: 33-56. doi: $10.2307 / 2399589$.

Rechinger, KH. (ed).1963-2005. Flora Iranica, No. 1-176. Akad. Druck-u. Verlagsanstalt, Graz.

Reveal JL, Chase MW. 2011. APG III: Bibliographical information and synonymy of Magnoliidae. Phytotaxa 19: 71-134. http:/mapress.com/phytotaxa/backissues.htm.

Shahina A. Khazanfar and John R. Edmondson, 2013. Flora of Iraq, Vol. 5, Part 2. Lythraceae to Campanulaceae, pages 307- 
312. With the collaboration of the staff of the national herbarium of Iraq of the Ministry of Agriculture, Baghdad. Stevens, P. F. 2001 onwards. Angiosperm Phylogeny Website. Version 14, July 2017 [and more or less continuously updated since]. will do. http://www.mobot.org/
The Plant List 2013. Version 1.1. Published on the Internethttp://www.theplantlist.org/ (accessed 1st January).

APPENDICES

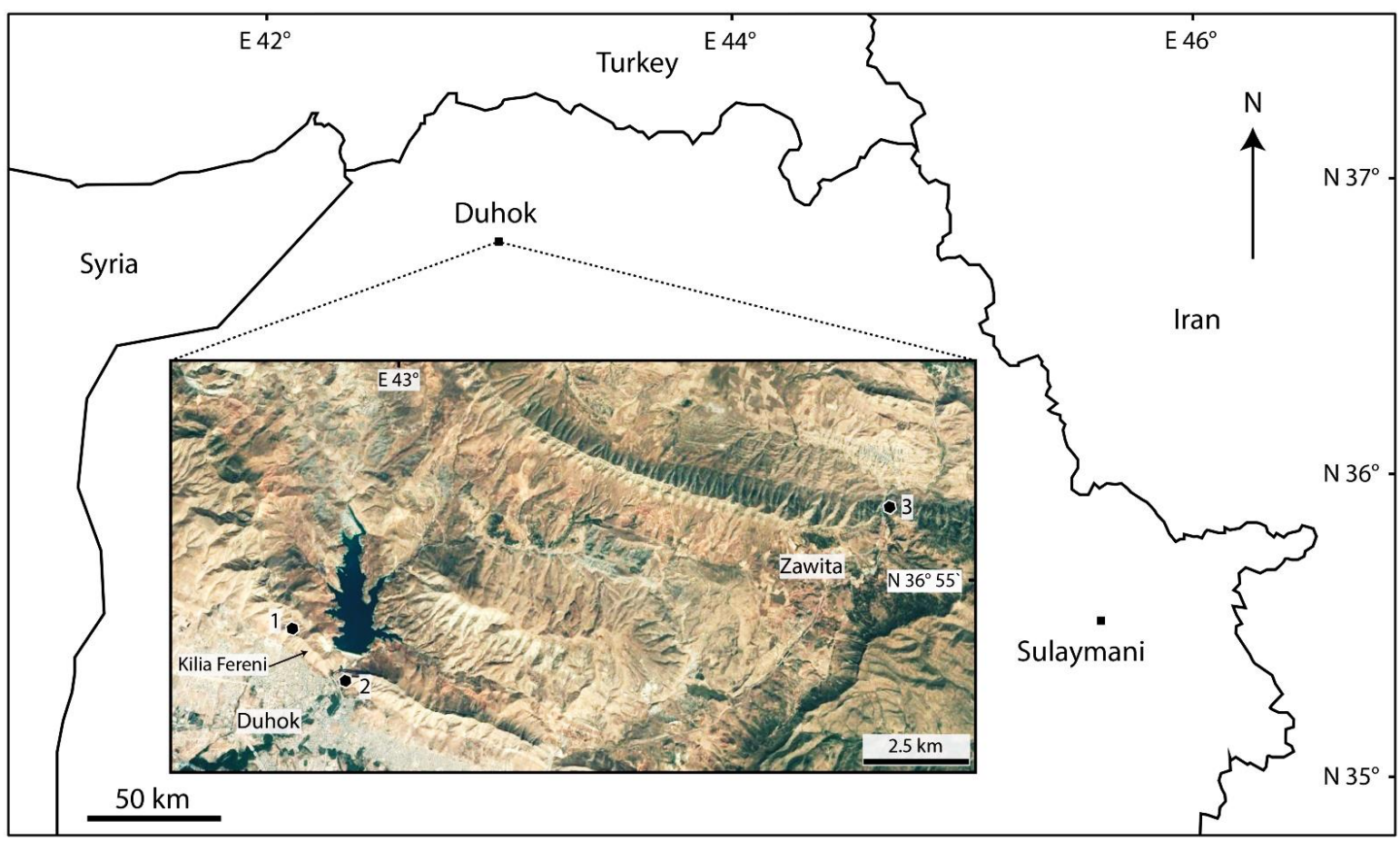

Figure 1. Map of Northern Iraq showing sites of P. tetraflorus in Duhok province: (1). Kilia fereni, ( 2). Duhok gorge, (3). Zawita gorge.

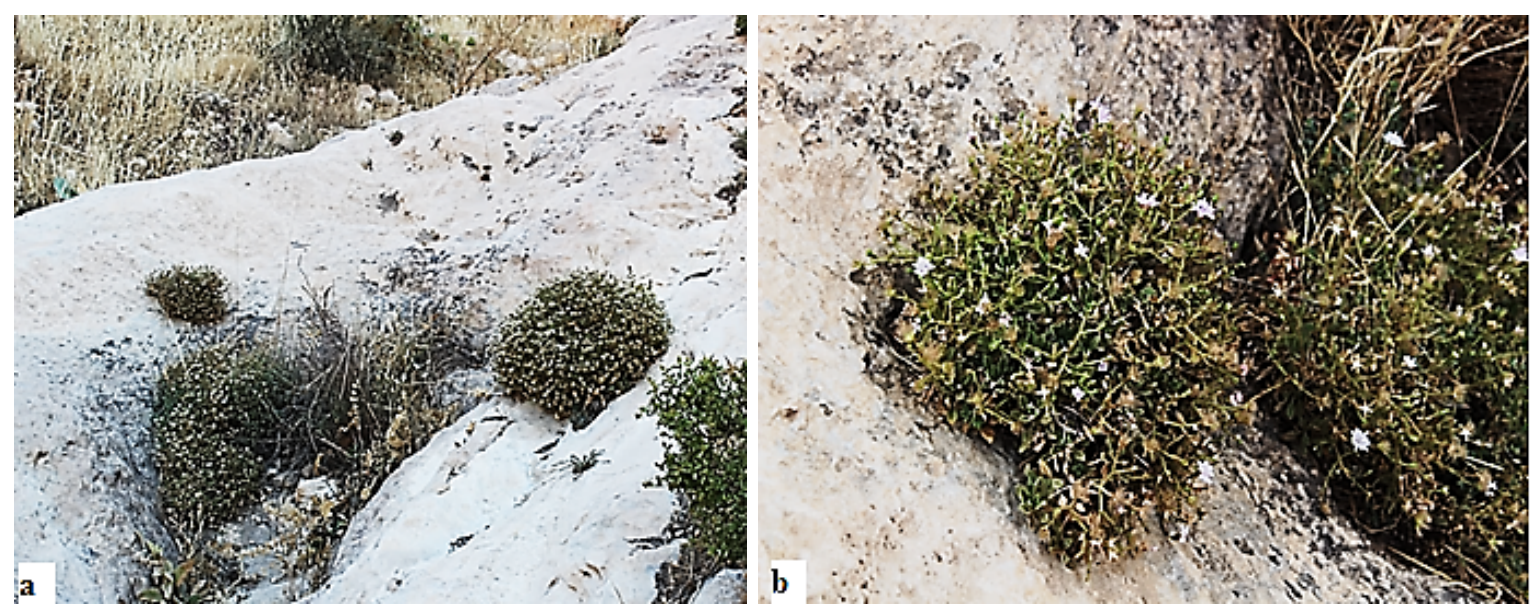

Figure 2. a and b. Habit and habitat of P. tetraflorus in Duhok province: Kilia fereni. 

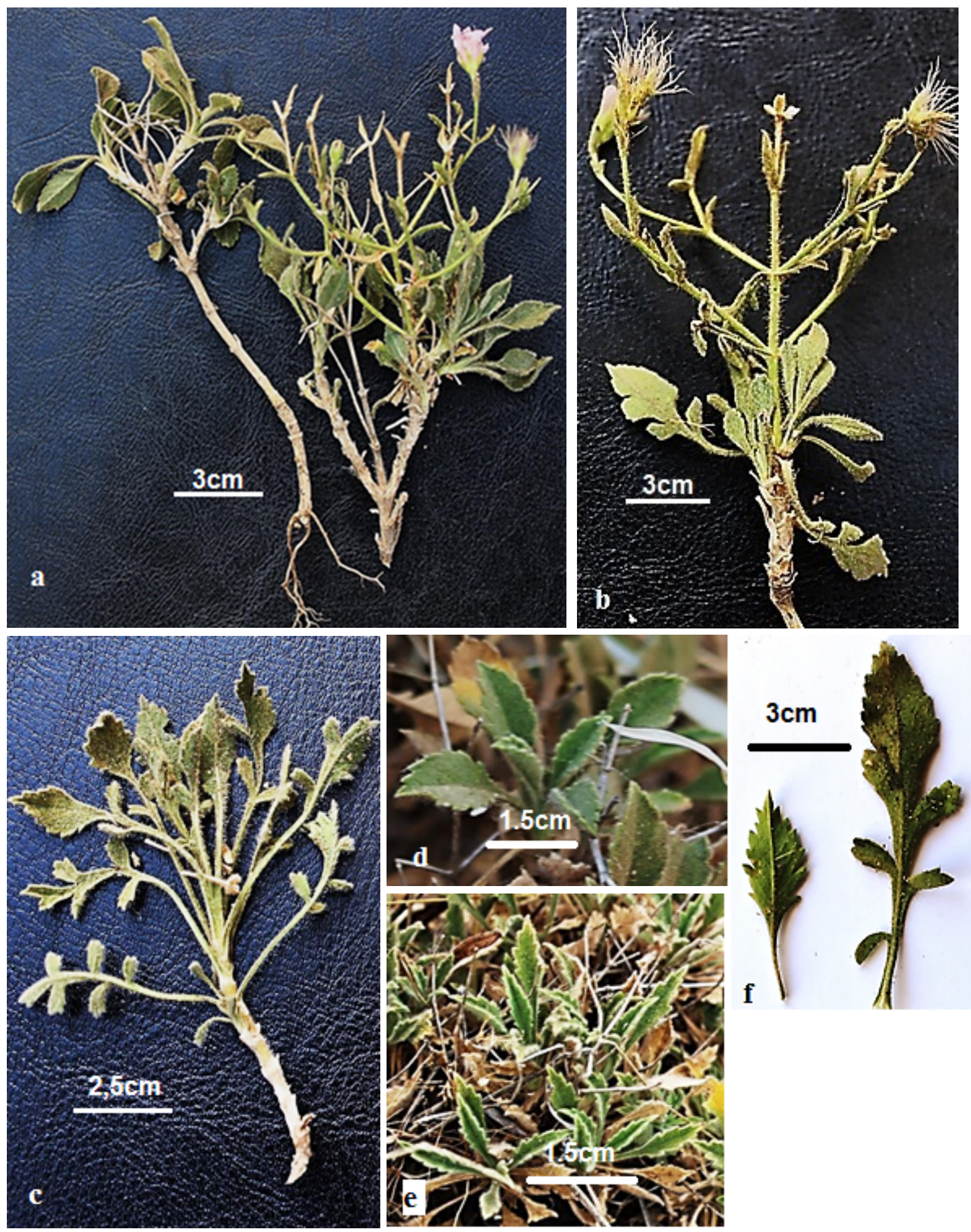

Figure 3. $a$ and b. Stem branches at fruiting stage, c. stem branch showing upper crowded simple leaves and lower dissected leaves, $\mathrm{d}$ and e, upper leaves, f. lower leaves. 

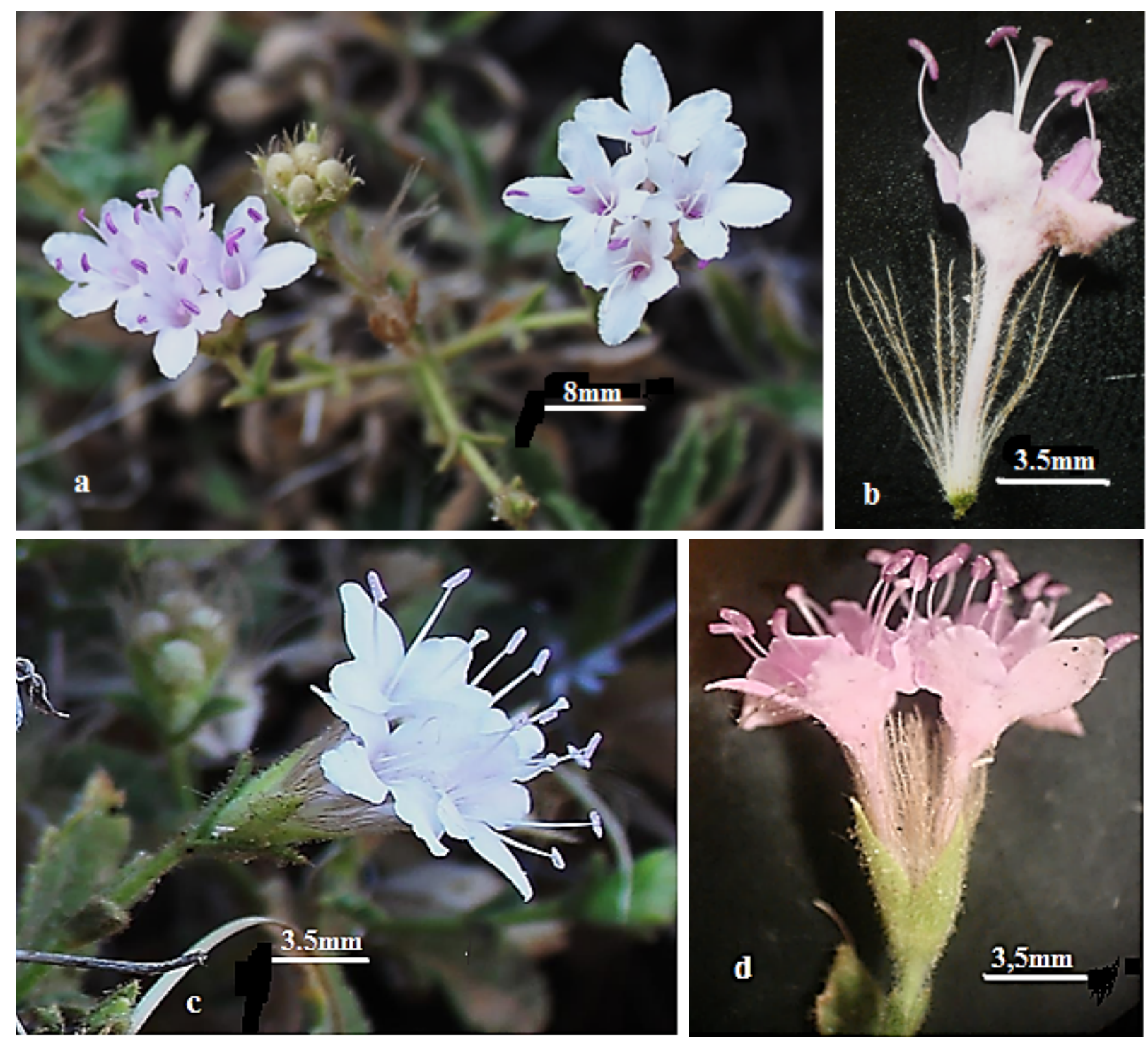

Figure 4. Flowers and inflorescences: a. Top view of inflorescences of four-flowered capitula, b. mature flower parts, c. side view of a whitish four-flowered capitula with four involucral bracts, d. side view of a pinkish four-flowered capitula with four involucral bracts. 

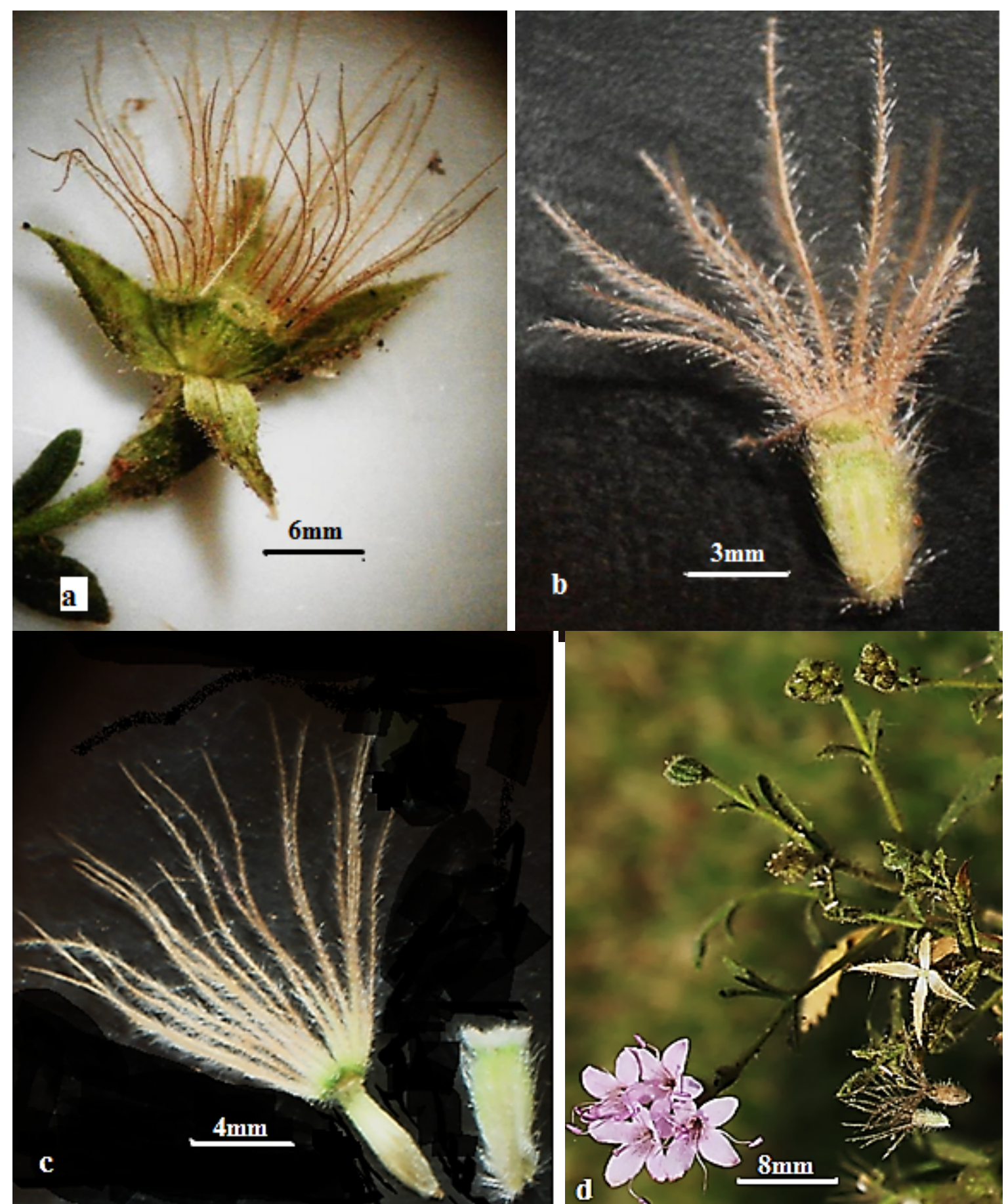

Figure 5. a. Four-fruited head with plumose calyx and enveloped by four involucral bracts and involucels with 6-8 prominent ribs, b. single fruit with plumose calyx and involucel densely hairy, c. naked fruit without involucel and the involucel removed and placed at the right side of the seed, the white corona topped the involucel, $d$. four flowered capitula and four fruited heads with separated fruits and white involucral bracts. 